\title{
Pharyngo-esophago-gastric dysmotility in intubated patients: A comprehensive review
}

\author{
Ulaş $\operatorname{KUMBASAR}^{1}$ (ID) \\ Pramod BONDE ${ }^{2}$ (ID)
}

\author{
${ }^{1}$ Section of Cardiothoracic Surgery, Yale School of Medicine, New Haven, \\ United States of America \\ ${ }^{1}$ Yale Tıp Fakültesi, Kardiyotorasik Cerrahi Bölümü, New Haven, \\ Amerika Birleşik Devletleri \\ 2 Section of Cardiac Surgery, Yale School of Medicine, New Haven, \\ United States \\ 2 Yale Tıp Fakültesi, Kardiyak Cerrahi Bölümü, New Haven, \\ Amerika Birleşik Devletleri
}

Cite this article as: Kumbasar U, Bonde P. Pharyngoesophago-gastric dysmotility in intubated patients: a comprehensive review. Tuberk Toraks 2021;69(3):392398.

Address for Correspondence (Yazışma Adresi)

\section{Dr. Ulaş KUMBASAR}

Section of Cardiothoracic Surgery, Yale School of Medicine, United States

NEW HAVEN - USA

e-mail: ulaskumbasar@gmail.com

CCopyright 2021 by Tuberculosis and Thorax.

Available on-line at www.tuberktoraks.org.com

\begin{abstract}
Pharyngo-esophago-gastric dysmotility in intubated patients: A comprehensive review

Postextubation swallowing dysfunction is a common phenomenon within the pharyngo-esophago-gastric dysmotility disorders. It is commonly seen after major surgery which requires endotracheal intubation for mechanical ventilation and associated with pulmonary complications which may lead to increased morbidity and mortality, prolonged hospital stay and increased cost. Thus, understanding the underlying mechanism of this phenomenon is crucial for early recognition and diagnosis of this entity, and to take preventive measures to minimize associated complications and morbidity. Literature search of the Medline database was performed to obtain related studies discussing pharyngo-esophago-gastric dysmotility. We focused on studies including PSD following major surgery and extracted data from the relevant studies, compared results, and summarized the related information. We reviewed the underlying mechanism, available diagnostic tools, risk factors, major pulmonary complications and their consequences, basic preventive measures and potential solutions related to this entity and aimed to guide physicians through decision-making process for their individual patients.
\end{abstract}

Key words: Intubation; dysphagia; swallowing; critical care; postoperative

Öz

Entübe hastalarda ortaya çıkan faringoözofagogastrik dismotilite: Güncel bir derleme

Ekstübasyon sonrası ortaya çıkan yutma disfonksiyonu, faringoözofagogastrik dismotilite bozukluklarından birisidir. Özellikle majör cerrahi sonrasında mekanik ventilasyon için entübasyonun gerekli olduğu durumlarda ortaya çıkar ve neden olduğu pulmoner komplikasyonlar nedeniyle artmış morbidite, mortalite, uzamış hastane yatısıı ve yüksek hastane maliyetine neden olabilir. 
Bu bozukluğun altında yatan mekanizmaların bilinmesi erken tanı olanağı sağlayarak olası komplikasyonları ve morbiditeyi azaltabilir. Bu amaçla, faringoözofagogastrik dismotilite ilgili güncel bir literatür taraması yaparak bu konuyla ilgili çalışmaları değerlendirdik. Majör cerrahisi sonrası ortaya çıkan dismotilite üzerine yoğunlaştık, elde ettiğimiz verileri karşılaştırdık ve özetlemeye çalıştık. Özellikle bu bozukluğa neden olan temel mekanizmaları, tanı yöntemlerini, risk faktörlerini, bu bozuklukla bağlantılı pulmoner komplikasyonları, alınabilecek önlemleri ve potansiyel çözümleri derleyerek bu konuyla karşılaşan klinisyenlere hastalarıyla ilgili karar verme aşamasında kılavuz olmayı amaçladık.

Anahtar kelimeler: Entübasyon; disfaji; yutma; yoğun bakım; postoperatif

\section{INTRODUCTION}

Postextubation swallowing dysfunction (PSD) is a common phenomenon seen in patients requiring endotracheal intubation for mechanical ventilation, especially after major surgery. It has a prevalence ranging from $44 \%$ to $62 \%$ in the literature. PSD may cause aspiration and results in pulmonary complications such as aspiration pneumonia which is associated with increased in-hospital morbidity and mortality, prolonged hospital stays, and financial burden (1-4).

Understanding the underlying mechanism of this phenomenon may help physicians to select proper screening tools which improve rates of early recognition and diagnosis, and the ability to take preventive measures which is essential to minimize related complications and morbidity. This article aims to review the underlying mechanism, available diagnostic tools, risk factors, major pulmonary complications and their consequences, basic preventive measures and potential solutions related to PSD. We also briefly focus on patients who underwent cardiac surgery as a special subpopulation at high risk for PSD and its related complications.

\section{MATERIALS and METHODS}

The aim of this review was to summarize and organize the data that is relevant to decision-making for individual patients. For this purpose, a literature search of the Medline database was performed to obtain related studies discussing pharyngo-esophago-gastric dysmotility, mostly focusing on PSD following major surgery. Fundamental concepts were extracted from these articles and combined appropriately. Main concepts also validated with supporting literature.

\section{Pathophysiology}

Pharyngeal and esophageal anatomy

The pharynx is composed of constrictor muscles that originate from the cranium, hyoid bone, and thyroid cartilage. The submental muscles attach to the hyoid bone and tongue and the cricopharyngeus muscle is attached to the sides of the cricoid cartilage. The epiglottis which originates in the larynx is attached to the hyoid bones anterior surface. The larynx contains the vocal folds and the laryngeal surface of the epiglottis. Muscles of the larynx are innervated by branches of cranial nerve $X$. The superior laryngeal nerve innervates cricothyroid, levator palatini, and constrictors of the pharynx, whereas the recurrent laryngeal nerve innervates the intrinsic muscles of the larynx $(5,6)$.

The esophagus is a hollow tubular organ composed of two muscle layers, an inner circular and outer longitudinal with the myenteric plexus between these. The upper esophageal sphincter (UES), which connects the pharynx to the proximal esophagus, is a high-pressure zone constructed by the cricopharyngeus, proximal cervical esophagus, and inferior pharyngeal constrictor. The UES is innervated by the vagus, glossopharyngeal nerves, and the sympathetic nerves of the cranial cervical ganglion. The distal part of the esophagus is composed of smooth muscle and forms the lower esophageal sphincter (LES) which works as an autonomous contractile apparatus (7).

\section{Physiology of swallowing}

The pharyngeal stage of swallowing has two important actions: (i) transport of the food through the phar$y n x$, UES to the esophagus; (ii) mechanisms of airway protection.

During this stage, the tongue base retracts, the soft palate elevates, and the food bolus is directed to the pharynx. The pharynx elevates and the sequential contraction of the pharyngeal constrictor muscles moves the bolus along. Contraction of the submental muscles move the larynx superior and anterior; the vocal folds and aryepiglottic folds adduct and the epiglottis folds over the glottal space all of which together prevent food bolus enters the lower airway. In addition, the movement of the larynx opens the superior portion of the esophageal sphincter. Contraction of the inferior pharyngeal muscle is fol- 
lowed by the relaxation of the upper esophageal sphincter. Additionally, contraction of the suprahyoid and thyrohyoid muscles pulls the hyo-laryngeal complex forward and helps to open the sphincter. Then, the bolus is passed into the esophagus. Once the bolus passes the UES, the esophageal stage starts. The peristalsis wave and the gravity carry the bolus down to the LES. Relaxation of the LES facilitates the transit of the bolus to the stomach $(6,8,9)$.

\section{Mechanism of esophagogastric dysmotility and diag- nostic tests}

As described above, swallowing is a complicated process that requires the coordination of various muscles and cranial nerves. Dysfunction in any of these processes can cause dysmotility of the food bolus leading to swallowing dysfunction which increases the risk of aspiration.

Potential mechanisms of swallowing dysfunction include (i) Direct trauma to the pharyngeal structures (glottis injury, mucosal inflammation, vocal cord ulcerations) caused by endotracheal or tracheostomy tubes. (ii) Muscular weakness and inactivity caused by nerve or muscular damage. (iii) Loss of sensation in the pharyngeal structures. (iv) Blunt airway protective reflexes due to impaired general sensorium caused by residual effects of drugs (narcotics, anxiolytics), sedation, and/or delirium. (v) Gastroesophageal reflux (10-12).

There are many tests used to assess swallowing function. These include videofluoroscopic swallow study (VFSS), fiberoptic endoscopic evaluation of swallowing (FEES), ultrasonography, $\mathrm{pH}$ monitoring, scintigraphy, and water-swallowing test. The gold standard test for the assessment of oropharyngeal dysphagia is considered VFSS or FEES. However, both tests are most probably be available at university-based hospitals rather than community-based hospitals (2). VFSS is the observation of the swallowing process with barium mixed food in the fluoroscopy suite. It has high inter-rater reliability as this observation is variable among radiologists. FEES allows direct visualization of the pharyngeal structures during swallowing. An endoscope is advanced into the pharynx and the glottis observed while the patient swallows. FEES has higher sensitivity and less interobserver variability than VFSS and can also be done at bedside. It also gives more detailed information about swallowing function, nearby structures, and tissue quality without radiation exposure $(3,13,14)$.
In practice, the most common test used for swallow evaluation is the water-swallowing test. The patient is observed at the bedside, ideally by a speech pathologist, for the development of aspiration signs or symptoms after swallowing three ounces of water. Although there is a $50 \%$ risk of silent aspiration that cannot be detected by this method, it is found to be $96.5 \%$ sensitive for swallowing dysfunction as detected by gold standard FEES performed afterward $(10,15)$.

There are no guidelines that can help physicians to choose the appropriate dysphagia screening method or to identify risk factors to better identify patients who should be tested for swallowing dysfunction following extubation. Thus, in routine practice, the decision regarding whom to screen or which method should be used are made by care teams on a case-bycase basis.

According to the available data, it seems reasonable to perform the water-swallowing test as an initial screening tool for patients at average risk for swallowing disorders after extubation and performing a more detailed assessment for patients who fail this test, or who are at higher risk for PSD.

Intubation and its effects on esophageal, pharyngeal and gastric motility

Prolonged mechanical ventilation (PMV) is defined as greater than 21 days of mechanical ventilation for at least six hours per day. It is estimated that $4 \%$ to $13 \%$ of mechanically ventilated patients require PMV. It prolongs the duration of hospital stay with major economic impacts and consequences on quality of life $(16,17)$. Although most patients undergoing major surgery can be extubated as soon as they have recovered from the anesthesia, up to $22.7 \%$ of these patients may require PMV with in-hospital mortality reaching to $40 \%(18-20)$.

PSD is commonly seen in trauma and critical care patients requiring endotracheal intubation for $\mathrm{MV}$ and may have many consequences including aspiration pneumonia, chemical pneumonitis, bronchospasm, and mechanical airway obstruction (3). The mechanism of PSD is multifactorial and explained in the previous section. The primary mechanism which leads to increased risk of PSD is laryngeal irritation or inflammation. Thus, PMV, presence of tracheostomy/ nasogastric tubes (especially large-bore tubes), or transesophageal echocardiography (TEE) probes increase the risk of developing this entity. In addition, 
advanced age, preexisting stroke, neuromuscular diseases, congestive heart failure, head and neck cancer are associated with a higher risk of PSD (2,21-23).

\section{Aspiration Pneumonia in Intubated Patients}

Tracheal aspiration, which is defined as the aspiration of gastric contents or pharyngeal secretions into the larynx and the lower respiratory tract, is a very common event with a prevalence of approximately $45 \%$ in normal individuals during sleep and $50-75 \%$ in patients with tracheal tubes.

Common risk factors for aspiration include the previous episode of aspiration, diminished consciousness, neuromuscular diseases, structural abnormalities of the aerodigestive tract, tracheal intubation, vomiting, high gastric residual volumes, nasoenteric tubes, intermittent feeding, major surgery or trauma, delayed gastric emptying, poor oral hygiene, and advanced age (24). However, all aspiration not necessarily results in aspiration pneumonia. Langmore et al. have defined three factors that potentially contribute to the development of aspiration pneumonia: occurrence of a pathogen in the aspirate, aspiration, and the failure of the alveolar tissue to react against the pathogen. Briefly, the occurrence of the aspiration pneumonia depends on the balance between the virulence of the aspirated pathogen and the host defense mechanism (25).

Nevertheless, when aspiration pneumonia occurs it is associated with an in-hospital mortality (odds ratio of around $7.4 \%$ ) with an estimated treatment cost of $\$ 22.000$ and is one of the leading causes of mortality in patients who are severely ill or who have undergone major surgery (1). Cardiothoracic procedures enhance the risk of aspiration pneumonia as they involve median sternotomy incision, dissection of internal mammary arteries, induction of hypothermia and extracorporeal circulation, and pulmonary parenchymal or airway surgery $(26,27)$. Various studies have investigated risk factors for postoperative aspiration pneumonia in patients who underwent cardiac surgery and reported advanced age, prolonged intubation, perioperative stroke, and use of TEE as the risk factors $(21,28,29)$. The major underlying mechanism among these risk factors is the occurrence of dysphagia. Grimm et al. have reported an $8.8 \%$ incidence of significant dysphagia in patients who underwent cardiac surgery (30). More recently, Miyata et al. have reported a $9.8 \%$ incidence of aspi- ration pneumonia following cardiac surgery in the elderly population, and the independent risk factors were previous cerebral vascular disorder and recent neurological deficit. In the univariate analysis, they also found low ejection fraction $(<30 \%)$ as an additional risk factor for aspiration pneumonia (27).

\section{Nasogastric tubes and risk of aspiration}

Enteral nutrition has an important role for critically ill and postoperative patients following prolong ICU stay by providing nutrients, regulating the immune response, and decreasing complications, thus improving prognosis (31). In many cases, nasogastric tubes (NGT) are placed for nutritional purposes and for preventing aspiration in patients with dysphagia. However, the association between NGTs and aspiration pneumonia is not clear. Enteral nutrition via NGT may disrupt the physiological protective mechanisms of the airways and leads to aspiration of the colonized pharyngeal and gastric contents. Besides, desensitization of the pharyngoglottal reflex by chronic stimulation of the pharynx and diminishing laryngeal sensitivity can predispose to laryngeal penetration and silent aspiration. The presence of NGT is also associated with a longer duration of upper esophageal sphincter opening and slowing of total swallowing (25,32-34). Some other newer studies have demonstrated that NGTs prolong the transit time and slow swallowing; nevertheless, they do not increase the risk of aspiration (35-37). More recently, Kim et al. have shown that the risk of aspiration is not significantly different before and after NGT removal, regardless of swallowing function, cognitive level, or general functional level of the patients (38).

There are two forms of enteral nutrition: gastric-tube feeding and post-pyloric feeding. It is still debatable which route of feeding is safer regarding the risk of aspiration pneumonia. While some studies demonstrated that post-pyloric feeding has lower incidence of pneumonia, others showed no significant difference between the two forms (39-41). Recently, Liu et al. conducted a meta-analysis to compare the safety of these routes by comparing the occurrence of pulmonary aspiration and nutrition-related outcomes in critical patients. Their review showed that post-pyloric feeding can reduce the risk of pulmonary aspiration, the occurrence of pneumonia, and other gastrointestinal complications. Thus, seems to be a safer form of feeding method than gastric-tube feeding (42). 


\section{Strategies for Prevention of Aspiration Pneumonia}

Preventive measures to reduce the occurrence of VAP in patients who underwent cardiac surgery should target the potential risk factors. These include efforts to improve cardiac and renal function, alleviate pulmonary hypertension, optimization of COPD symptoms, minimizing CPB time, limiting the use of unnecessary blood product use, and most importantly reducing MV time, avoidance of reintervention, and reintubation (43-45). To identify high-risk patients for VAP, Hortal et al. have developed a scoring tool. Day 0 score includes preoperative variables and day 3 scoring is used for patients who remained ventilated for more than 48 hours. By using this tool, they were capable of identifying $93 \%$ of patients who would develop VAP with a specificity of $40 \%$ (46).

In addition to these preventive measures, some steps can be taken to reduce the occurrence of aspiration pneumonia. These mostly focus on reducing dysphagia and preventing aspiration and include feeding patients via a post-pyloric route with properly sized tubes, cautious use of drugs that may impair airway protective mechanisms, avoiding unnecessary use of TEE probes, improving oral hygiene before surgery, and above all proper management of PSD $(10,11,47$ 49).

\section{CONCLUSION}

The clinical assessment of swallowing with water-swallowing is the initial screening method for patients after extubation. However, its sensitivity is still low for detecting silent aspiration. Therefore, speech-language pathologists should be educated to assess swallowing and treat oral motor dysfunction, manage cervical muscle rehabilitation, and give advice about the onset of oral food intake. Besides, these speech-language pathologists should be incorporated into multidisciplinary teams and help to reduce complications resulting from $\operatorname{PSD}(11,14,50)$.

Potential therapeutic options for PSD are dietary texture modifications, postural changes and compensatory maneuvers, interventions to improve swallow function, therapeutic exercises, and neuromuscular stimulation. Adjusting the patient's position to $90^{\circ}$ upright or $45^{\circ}$ sitting with chin down position and swallowing maneuvers, such as intake of small amounts per swallow can help to improve food passage and reduce airway aspiration (3).
Therapeutic exercises also support motor control and help to decrease the risk of aspiration. Interventions, such as neuromuscular electrical stimulation, cricopharyngeal botulinum toxin injection, and surface electromyography biofeedback are also helpful to improve swallowing function in patients with underlying neuromuscular disorders $(3,51,52)$.

\section{REFERENCES}

1. Kozlow JH, Berenholtz SM, Garrett E, Dorman T, Pronovost P). Epidemiology and impact of aspiration pneumonia in patients undergoing surgery in Maryland, 1999-2000. Crit Care Med 2003; 31(7): 1930-7.

2. Macht $M$, Wimbish T, Clark BJ, Benson AB, Burnham EL, Williams $A$, et al. Diagnosis and treatment of post-extubation dysphagia: results from a national survey. I Crit Care 2012; 27(6): 578-86.

3. Rassameehiran S, Klomjit S, Mankongpaisarnrung C, Rakvit A. Postextubation Dysphagia. Proc (Bayl Univ Med Cent) 2015; 28(1): 18-20.

4. Skoretz SA, Flowers HL, Martino R. The incidence of dysphagia following endotracheal intubation: a systematic review. Chest 2010; 137(3): 665-73.

5. Jadcherla SR, Hogan WI, Shaker R. Physiology and pathophysiology of glottic reflexes and pulmonary aspiration: from neonates to adults. Semin Respir Crit Care Med 2010; 31(5): 554-60.

6. Matsuo K, Palmer JB. Anatomy and physiology of feeding and swallowing: normal and abnormal. Phys Med Rehabil Clin N Am 2008; 19(4): 691-707, vii.

7. Lang IM, Shaker R. Anatomy and physiology of the upper esophageal sphincter. Am J Med 1997; 103(5A): 50S-5S.

8. Ohmae Y, Logemann JA, Kaiser P, Hanson DG, Kahrilas PJ. Timing of glottic closure during normal swallow. Head Neck 1995; 17(5): 394-402.

9. Shaw DW, Cook IJ, Gabb M, Holloway RH, Simula ME, Panagopoulos $V$, et al. Influence of normal aging on oral-pharyngeal and upper esophageal sphincter function during swallowing. Am J Physiol 1995; 268(3 Pt 1): G38996.

10. Macht M, Wimbish T, Bodine C, Moss M. ICU-acquired swallowing disorders. Crit Care Med 2013; 41(10): 2396405.

11. Medeiros GC, Sassi FC, Mangilli LD, Zilberstein B, Andrade $C R$. Clinical dysphagia risk predictors after prolonged orotracheal intubation. Clinics (Sao Paulo) 2014; 69(1): 8-14.

12. Tolep K, Getch CL, Criner GJ. Swallowing dysfunction in patients receiving prolonged mechanical ventilation. Chest 1996; 09(1): 167-72. 
13. Ajemian MS, Nirmul GB, Anderson MT, Zirlen DM, Kwasnik EM. Routine fiberoptic endoscopic evaluation of swallowing following prolonged intubation: implications for management. Arch Surg 2001; 136(4): 434-7.

14. Ott DJ. Observer variation in evaluation of videofluoroscopic swallowing studies: a continuing problem. Dysphagia 1998; 13(3): 148-50.

15. Suiter DM, Leder SB. Clinical utility of the 3-ounce water swallow test. Dysphagia 2008; 23(3): 244-50.

16. Lone NI, Walsh TS. Prolonged mechanical ventilation in critically ill patients: epidemiology, outcomes and modelling the potential cost consequences of establishing a regional weaning unit. Crit Care 2011; 15(2): R102.

17. Maclntyre NR, Epstein SK, Carson S, Scheinhorn D, Christopher K, Muldoon S, et al. Management of patients requiring prolonged mechanical ventilation: report of a NAMDRC consensus conference. Chest 2005; 128(6): 3937-54.

18. Rajakaruna C, Rogers CA, Angelini GD, Ascione R. Risk factors for and economic implications of prolonged ventilation after cardiac surgery. I Thorac Cardiovasc Surg 2005; 130(5): 1270-7.

19. Thompson MJ, Elton RA, Mankad PA, Campanella C, Walker WS, Sang CT, et al. Prediction of requirement for, and outcome of, prolonged mechanical ventilation following cardiac surgery. Cardiovasc Surg 1997; 5(4): 376-81.

20. Trouillet IL, Combes A, Vaissier E, Luyt CE, Ouattara A, Pavie A, et al. Prolonged mechanical ventilation after cardiac surgery: outcome and predictors. I Thorac CardiovasC Surg 2009; 138(4): 948-53.

21. Barker J, Martino R, Reichardt B, Hickey EJ, Ralph-Edwards A. Incidence and impact of dysphagia in patients receiving prolonged endotracheal intubation after cardiac surgery. Can J Surg 2009; 52(2)119-24.

22. Barquist E, Brown $M$, Cohn S, Lundy D, Jackowski J. Postextubation fiberoptic endoscopic evaluation of swallowing after prolonged endotracheal intubation: a randomized, prospective trial. Crit Care Med 2001; 29(9): 1710-3.

23. Rousou JA, Tighe DA, Garb IL, Krasner H, Engelman RM, Flack JE, $3^{\text {rd }}$, et al. Risk of dysphagia after transesophageal echocardiography during cardiac operations. Ann Thorac Surg 2000; 69(2): 486-9; discussion 9-90.

24. McClave SA, DeMeo MT, DeLegge MH, DiSario JA, Heyland DK, Maloney JP, et al. North American Summit on Aspiration in the Critically III Patient: consensus statement. JPEN J Parenter Enteral Nutr 2002; 26(6 Suppl): S80-5.

25. Langmore SE, Terpenning MS, Schork A, Chen Y, Murray JT, Lopatin D, et al. Predictors of aspiration pneumonia: how important is dysphagia? Dysphagia 1998; 13(2): 69-81.

26. Kollef MH, Skubas NJ, Sundt TM. A randomized clinical trial of continuous aspiration of subglottic secretions in cardiac surgery patients. Chest 1999; 116(5): 1339-46.
27. Miyata E, Tanaka A, Emori H, Taruya A, Miyai S, Sakagoshi $N$. Incidence and risk factors for aspiration pneumonia after cardiovascular surgery in elderly patients. Gen Thorac Cardiovasc Surg 2017; 65(2): 96-101.

28. Hogue CW, Jr., Lappas GD, Creswell LL, Ferguson TB, Jr., Sample M, Pugh D, et al. Swallowing dysfunction after cardiac operations. Associated adverse outcomes and risk factors including intraoperative transesophageal echocardiography. I Thorac Cardiovasc Surg 1995; 110(2): 517-22.

29. Skoretz SA, Yau TM, Ivanov J, Granton JT, Martino R. Dysphagia and associated risk factors following extubation in cardiovascular surgical patients. Dysphagia 2014; 29(6): 647-54.

30. Grimm JC, Magruder JT, Ohkuma R, Dungan SP, Hayes A, Vose AK, et al. A Novel Risk Score to Predict Dysphagia After Cardiac Surgery Procedures. Ann Thorac Surg 2015; 100(2): 568-74.

31. McClave SA, Taylor BE, Martindale RG, Warren MM, Johnson DR, Braunschweig $C$, et al. Guidelines for the Provision and Assessment of Nutrition Support Therapy in the Adult Critically III Patient: Society of Critical Care Medicine (SCCM) and American Society for Parenteral and Enteral Nutrition (A.S.P.E.N.). JPEN J Parenter Enteral Nutr 2016; 40(2): 159-211.

32. Kirby $D F$, Delegge $M H$, Fleming CR. American Gastroenterological Association technical review on tube feeding for enteral nutrition. Gastroenterology 1995; 108(4): 1282-301.

33. Mittal RK, Stewart WR, Schirmer BD. Effect of a catheter in the pharynx on the frequency of transient lower esophageal sphincter relaxations. Gastroenterology 1992; 103(4): 1236-40.

34. Huggins PS, Tuomi SK, Young C. Effects of nasogastric tubes on the young, normal swallowing mechanism. Dysphagia 1999; 14(3): 157-61.

35. Fattal M, Suiter DM, Warner HL, Leder SB. Effect of presence/absence of a nasogastric tube in the same person on incidence of aspiration. Otolaryngol Head Neck Surg 2011; 145(5): 796-800.

36. Leder SB, Suiter DM. Effect of nasogastric tubes on incidence of aspiration. Arch Phys Med Rehabil 2008; 89(4): 648-51.

37. Wang TC, Wu MC, Chang YC, Hsiao TY, Lien IN. The effect of nasogastric tubes on swallowing function in persons with dysphagia following stroke. Arch Phys Med Rehabil 2006; 87(9): 1270-3.

38. Kim G, Baek S, Park H-W, Kang EK, Lee G. Effect of Nasogastric Tube on Aspiration Risk: Results from 147 Patients with Dysphagia and Literature Review. Dysphagia 2018; 33(6): 731-8.

39. Acosta-Escribano J, Fernandez-Vivas M, Grau Carmona T, Caturla-Such J, Garcia-Martinez M, Menendez-Mainer A, et al. Gastric versus transpyloric feeding in severe traumatic brain injury: a prospective, randomized trial. Intensive Care Med 2010; 36(9): 1532-9. 
40. Friedman G, Flavia Couto CL, Becker M. Randomized study to compare nasojejunal with nasogastric nutrition in critically ill patients without prior evidence of altered gastric emptying. Indian J Crit Care Med 2015; 19(2): 71-5.

41. Taylor SJ, Allan K, McWilliam H, Manara A, Brown J, Greenwood $R$, et al. A randomised controlled feasibility and proof-of-concept trial in delayed gastric emptying when metoclopramide fails: We should revisit nasointestinal feeding versus dual prokinetic treatment: Achieving goal nutrition in critical illness and delayed gastric emptying: Trial of nasointestinal feeding versus nasogastric feeding plus prokinetics. Clin Nutr ESPEN 2016; 14: 1-8.

42. Liu Y, Wang Y, Zhang B, Wang J, Sun L, Xiao Q. Gastric-tube versus post-pyloric feeding in critical patients: a systematic review and meta-analysis of pulmonary aspiration- and nutrition-related outcomes. Eur J Clin Nutr 2021.

43. He S, Chen B, Li W, Yan J, Chen L, Wang X, et al. Ventilatorassociated pneumonia after cardiac surgery: A meta-analysis and systematic review. I Thorac Cardiovasc Surg 2014; 148(6): 3148-55.e5.

44. Poelaert J, Depuydt P, De Wolf A, Van de Velde S, Herck I, Blot S. Polyurethane cuffed endotracheal tubes to prevent early postoperative pneumonia after cardiac surgery: a pilot study. J Thorac Cardiovasc Surg 2008; 135(4): 771-6.

45. Segers $P$, de Mol BA. Prevention of ventilator-associated pneumonia after cardiac surgery: prepare and defend! Intensive Care Med 2009; 35(9): 1497-9.

46. Hortal J, Giannella M, Perez MJ, Barrio JM, Desco M, Bouza $E$, et al. Incidence and risk factors for ventilator-associated pneumonia after major heart surgery. Intensive Care Med 2009; 35(9): 1518-25.
47. Alecrim RX, Taminato M, Belasco A, Longo MCB, Kusahara $D M$, Fram D. Strategies for preventing ventilator-associated pneumonia: an integrative review. Revista Brasileira de Enfermagem 2019; 72(2): 521-30.

48. Hassoun-Kheir $N$, Hussein $K$, Abboud $Z$, Raderman $Y$, Abu-Hanna L, Darawshe A, et al. "Risk factors for ventilator-associated pneumonia following cardiac surgery: case-control study". J Hosp Infect 2020.

49. Kim JW, Choi H, Jung J, Kim HJ. Risk factors for aspiration pneumonia in patients with dysphagia undergoing videofluoroscopic swallowing studies: A retrospective cohort study. Medicine (Baltimore) 2020; 99(46): e23177.

50. Hinds NP, Wiles CM. Assessment of swallowing and referral to speech and language therapists in acute stroke. QJM 1998; 91(12): 829-35.

51. Alfonsi E, Merlo IM, Ponzio M, Montomoli C, Tassorelli C, Biancardi C, et al. An electrophysiological approach to the diagnosis of neurogenic dysphagia: implications for botulinum toxin treatment. I Neurol Neurosurg Psychiatry 2010; 81(1): 54-60.

52. Clark H, Lazarus C, Arvedson J, Schooling T, Frymark T. Evidence-based systematic review: effects of neuromuscular electrical stimulation on swallowing and neural activation. Am J Speech Lang Pathol 2009; 18(4): 361-75. 